\title{
Reproductive characteristics of the bathyal viviparous fish Cataetyx alleni (Osteichthyes: Bythitidae) from the southeastern Sardinian Sea (central-western Mediterranean)
}

\author{
MARIA CRISTINA FOLLESA, CRISTINA PORCU, ANTONELLO MULAS, \\ SUSANNA SALVADORI and ANGELO CAU \\ Department of Animal Biology and Ecology, University of Cagliari, Via T. Fiorelli, 1, 09126 Cagliari, Italy.E- mail: \\ follesac@unica.it
}

\begin{abstract}
SUMMARY: The reproductive biology of the bathyal viviparous fish Cataetyx alleni was described based on 34 specimens (17 females and 17 males) caught during experimental trawl surveys carried out between 800 and $1700 \mathrm{~m}$ depth in the southeastern Sardinian Sea (central-western Mediterranean). Males and females were present at similar size intervals. For the first time, the internal fertilization was demonstrated by the finding of free spermatozoa scattered in the ovarian cavity. Based on macroscopic and histological gonad analysis, mature females were found in summer, autumn and winter, suggesting a long reproductive period. Inseminated females were observed only in November and January, in correspondence with the higher maturity of the males. These results suggest a probable reproductive peak with copulation in autumn-winter. Moreover, histological examination demonstrated that the ovaries of this member of the family Bythitidae had a 'group-synchronous' pattern. No spermatophores in males and embryos in females were observed in the histological sections analysed.
\end{abstract}

Keywords: Cataetyx alleni, reproduction, internal fertilization, Sardinian Sea.

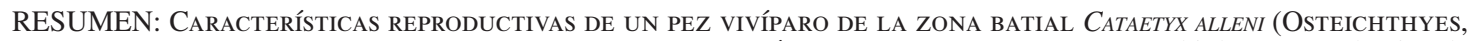
Bythitidae) EN El SURESTe del MAR De Cerdeña (MediterRáneo CENTRO-OCCIDENTAL). - La biología reproductiva de Cataetyx alleni, un pez vivíparo batial, fue descrita basándose en el examen de 34 especímenes (17 hembras y 17 machos) capturados durante las campañas experimentales de pesca de arrastre conducidas entre 800 y 1700 metros de profundidad en el sureste del mar de Cerdeña (Mediterráneo centro-occidental). Hembras y machos presentaron tallas similares. Por primera vez, la fecundación interna fue demostrada gracias al descubrimiento de espermatozoos libres dispersos en la cavidad del ovario. Basándose en análisis macroscópicos e histológicos, las hembras maduras fueron encontradas en verano, otoño e invierno, sugiriendo un periodo reproductivo muy largo. Las hembras fecundadas fueron observadas sólo durante el mes de Noviembre y Enero, conjuntamente con los machos de madurez máxima. Estos datos podrían suponer un posible máximo reproductivo con cópula durante el otoño y el invierno. Además, los exámenes histológicos demostraron que los ovarios de este Bythitidae presentan un modelo de sincronización de grupo. Ningún espermatóforo ni embriones fueron observados en las secciones histológicas analizadas.

Palabras clave: Cataetyx alleni, reproducción, fecundación interna, mar de Cerdeña.

\section{INTRODUCTION}

The reproduction of the more than 20000 species of teleostean fishes includes both oviparity and viviparity (Wourms, 1991). In the oviparity adopted by most species, males and females release sperm and eggs in the aquatic environment almost at once. On the other hand, viviparity has been found in approximately 510 species (Wourms, 1991). In these species, females copulate with males and eggs are fertilized internally with sperm. Therefore, embryos at various embryonic stages are usually found in the ovaries of collected fishes. 
The Bythithoidei are viviparous, a style confirmed by the presence of an intromittent organ in males (Cohen and Nielsen, 1978). The brotulas of the family Bythitidae are small benthic fishes that inhabit shallow waters of the continental slope, with circumglobal distribution in tropical and temperate waters (Leis and Rennis, 2000). Viviparity is one of the adaptations which allows brotulas to occupy a wide range of habitats.

The family contains 107 species included in 37 genera (Nelson, 2006). All bythitids are livebearers (Wourms and Bayne, 1973; Goodwin et al., 2002) and release elongate larvae with a striated gut.

The genus Cataetyx has a worldwide distribution in tropical and temperate regions (Bañón, 2001) and contains 12 known species. It is represented in the Mediterranean Sea by two species, Cataetyx alleni (Byrne, 1906) and Cataetyx laticeps Koefoed, 1927 (Nielsen, 1986), which are closely associated with depths greater than $1000 \mathrm{~m}$ (Stefanescu et al., 1992).

Cataetyx alleni is benthic, usually found below $600 \mathrm{~m}$ and not commercially important. The species is distributed in the western basin [Catalan Sea between 984 and $1851 \mathrm{~m}$ (Matallanas, 1983; Stefanescu et al., 1992), Balearic Islands between 700 and $1600 \mathrm{~m}$ (Moranta et al., 1998, 2004; Morales-Nin, 2001), Ligurian Sea between 473 and 750 m (Relini Orsi, 1971, 1974; Relini et al., 1986) and Sardinian Channel between 800 and $1420 \mathrm{~m}$ (Follesa et al., 2005, 2010)], and in the eastern basin only in the southern Adriatic Sea between 1074 and $1196 \mathrm{~m}$ (Ungaro et al., 2001). Only a few specimens of $C$. alleni have been collected in the eastern North Atlantic (Porcupine Seabight) between 770 and $1205 \mathrm{~m}$ (Merrett et al., 1991).

During the last few decades many studies of the biology of this species in the Catalan Sea have dealt with the feeding ecology (Carrassón and Matallanas, 1990, 2002), morphological characteristics of the digestive tract (Carrassón and Matallanas, 1994) and trophic relationships among the fish assemblages (Carrassón and Cartes, 2002). Only Relini Orsi (1974) provided some information on the reproductive anatomy and biology of this species.

As the reproductive biology of $C$. alleni has received little attention, the aim of our work was to provide further information on the reproductive characteristics (internal fertilization, maturity and spawning period) of this species caught in southeastern Sardinian deep waters (central-western Mediterranean) at depths of between 800 and $1700 \mathrm{~m}$.

\section{MATERIALS AND METHODS}

A total of 34 specimens of C. alleni were caught during seasonal experimental trawl surveys carried out between 793 and $1701 \mathrm{~m}$ depth on compact mud bottoms off southeastern Sardinian deep waters (centralwestern Mediterranean) (Fig. 1). Table 1 shows the indication of the positive hauls by month, depth range (m) and number of specimens collected.

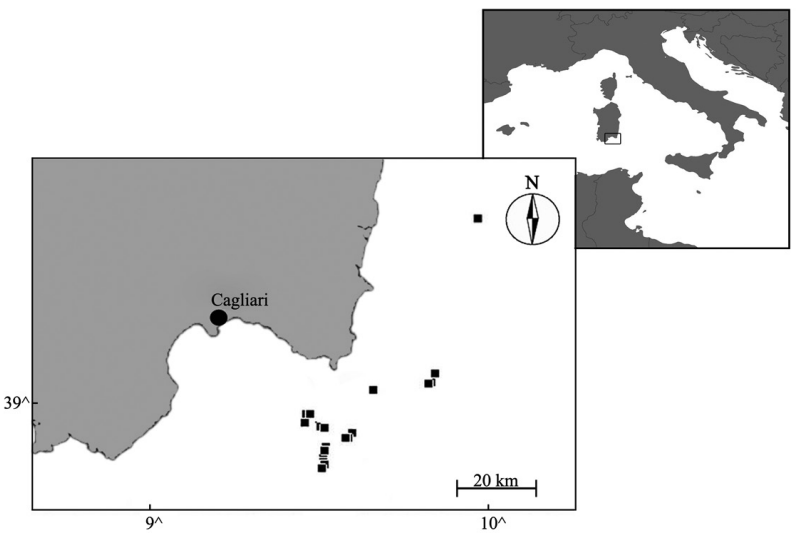

FIG. 1. - Map of the study area and position of trawl stations (black squares) off southeastern Sardinian deep waters where the specimens of Cataetyx alleni were caught.

For each specimen the standard length (SL) was measured to the nearest $\mathrm{mm}$. Total weight (TW) was recorded to the nearest $\mathrm{g}$.

All fishes were dissected and the gonads were removed and classified according to the criteria of Holden and Raitt (1975): I, immature; II, developing; III, maturing; IV, mature and V, spent. A piece of tissue from the middle region of the gonad was cut and preserved in 5\% saline formol and subsequently processed histologically to enable the observation of the process of

TABLE 1. - Indication of the positive hauls by month, depth range (m) and number of specimens collected of Cataetyx alleni.

\begin{tabular}{llcc}
\hline Haul & Month & $\begin{array}{c}\text { depth range } \\
(\mathrm{m})\end{array}$ & $\begin{array}{c}\text { Total number of } \\
\text { specimens }\end{array}$ \\
\hline 002PSP05 & January & $880-1006$ & 6 \\
003PSP05 & & & \\
004PSP06 & & & \\
005PSP06 & & $1133-1420$ & 6 \\
002PSP07 & March & \\
003PSP07 & & & \\
004PSP07 & & & \\
008PSP05 & May & \\
008PSP06 & & & \\
009PSP06 & & 1198 & \\
012PSP05 & & $1001-1420$ & 6 \\
008PSP03 & June & \\
012PSP06 & July & & \\
013PSP06 & & 1420 & \\
015PSP06 & & & \\
005PSP09 & August & & \\
011PSP04 & September & $1125-1701$ & \\
014PSP04 & & & \\
007PSP09 & & & \\
016PSP06 & November & $793-1202$ & \\
017PSP03 & & & \\
018PSP03 & & & \\
018PSP06 & & & \\
019PSP03 & & & \\
022PSP03 & & & \\
\hline
\end{tabular}



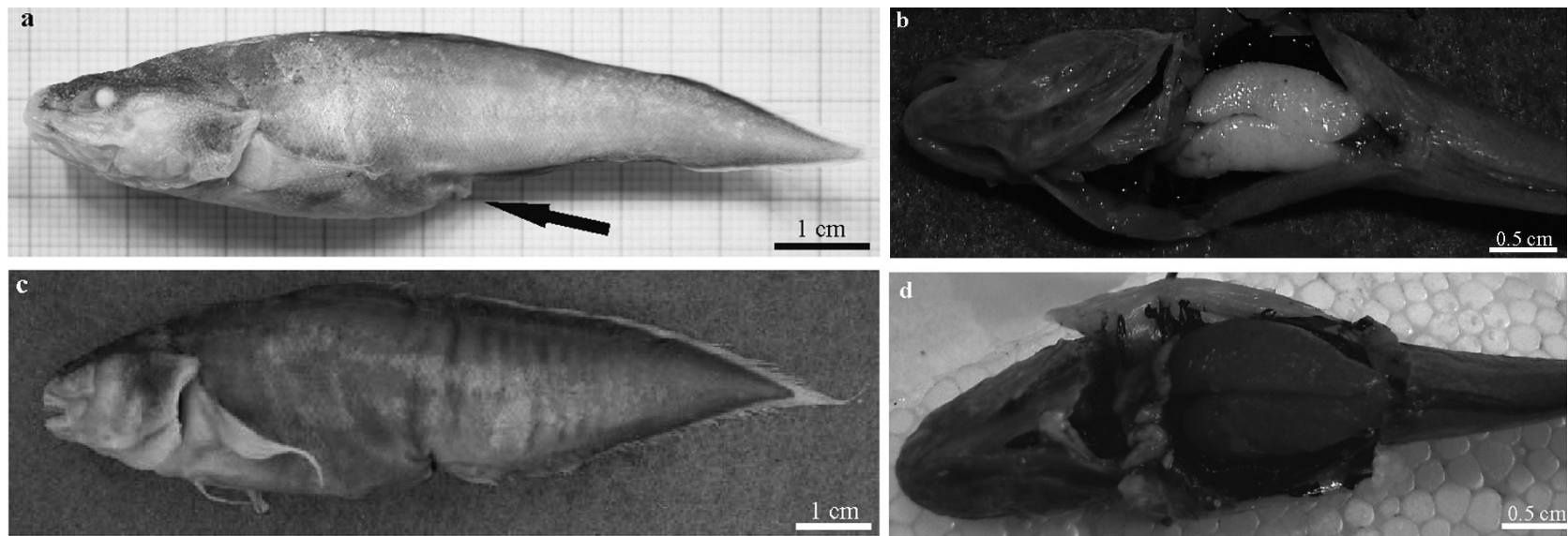

FIG. 2. - a) Males of Cataetyx alleni with copulatory organ (arrow); b) mature testes; c) females of Cataetyx alleni; d) mature ovaries.

gonadal development. Transverse sections of $3.5 \mu \mathrm{m}$ (glycol-methacrylate method) were stained with Harris hematoxylin and counterstained with eosin. Oocyte development stages were identified according to the scale proposed by Wallace and Selman (1981), whereas the development stages of the testicular germinal cells were identified based on the spermatogenic differentiation developed by Grier (1981), both with the use of an optic microscope (Laborlux 12) at original magnification x25-400. Oocyte size and number of a defined number of microscopic fields, obtained by taking the mean and maximum diameter, were only recorded from those oocytes which had been sectioned through the nucleus with the image analysis program, tpsDig2 (Rohlf, 2005).

\section{RESULTS}

The length sizes of $C$. alleni, showed a standard length (SL) ranging between 43 and $116 \mathrm{~mm}$, with a mean \pm SD of $81 \pm 18.9 \mathrm{~mm}$. Of the total of individuals caught $(n=34)$, macroscopically 17 were females and 17 were males. Males and females were present at similar size intervals: the length ranged between 43 and $116 \mathrm{~mm}$ SL (mean 82 $20.2 \mathrm{~mm}$ ) and 64 and 106 $\mathrm{mm}$ SL (mean $86 \pm 13.4 \mathrm{~mm}$ ) for males and females, respectively.

Males of $C$. alleni were characterized by a copulatory shield-shaped organ found after the anal opening, showing a flattened portion at rest on the ventral side,
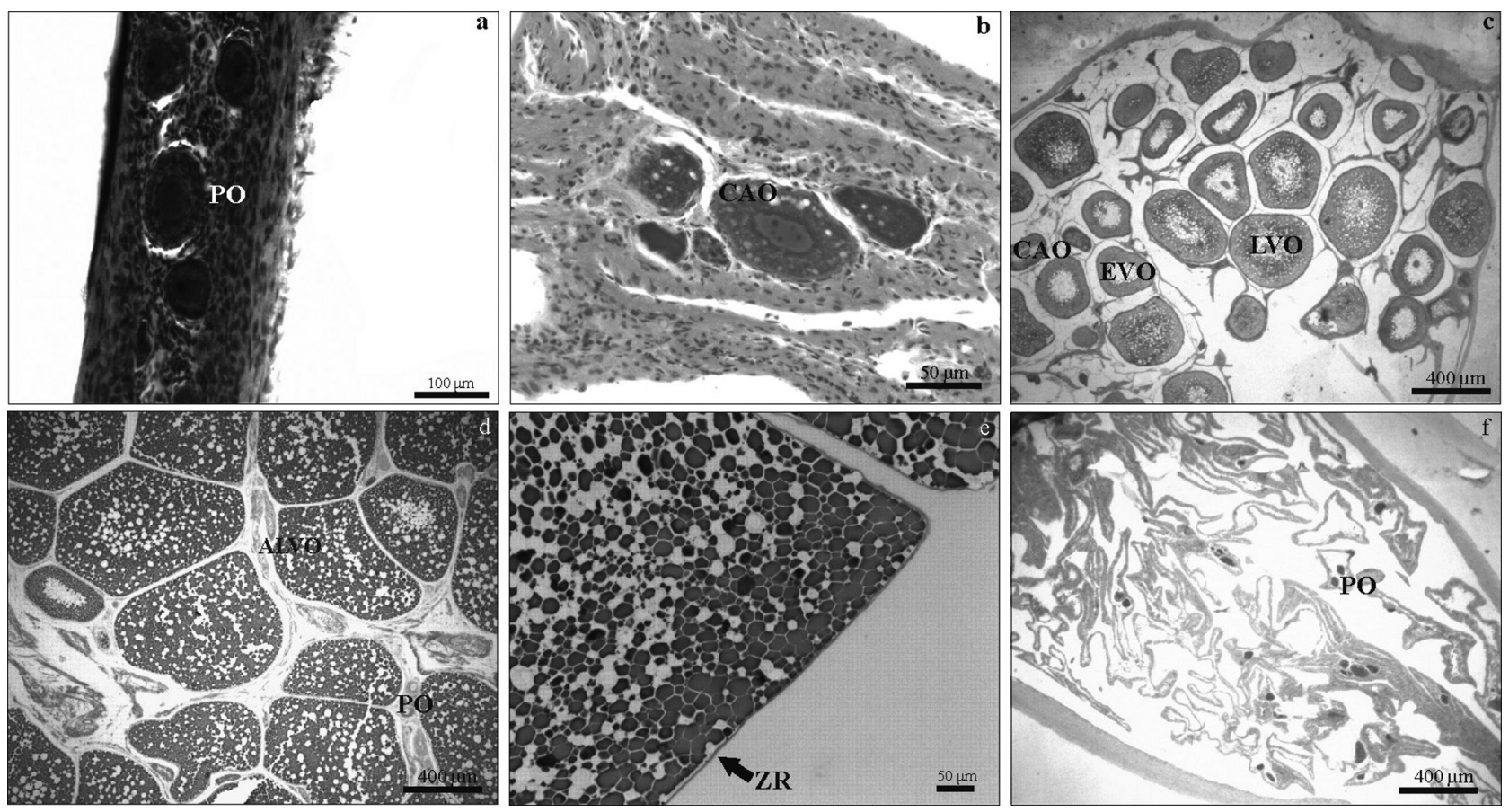

FIG. 3. - Transverse sections of Cataetyx alleni females illustrating oogenesis. a) Immature stage (I): PO, primary oocytes. (b) developing stage (II): CAO, cortical alveoli oocytes. (c) maturing stage (III): CAO, cortical alveoli oocytes; EVO, early vitellogenic oocytes; and LVO, late vitellogenic oocytes. (d) mature stage (IV) with advanced late vitellogenic oocytes (ALVO). (f) Thinness of the zona radiata (ZR) in ALVO. (f) post-spawning stage $(\mathrm{V})$. 
whose posterior margin is invaginated like a glove finger (Fig. 2a).

Females showed no detectable sexual character (Fig. 2c). The gonads are saccular (Fig. 2d) and merge to the caudal tip and the connective tissue capsule surrounding them continues in a short and unequal oviduct.

The macroscopic and microscopic stages of female maturity were as follows:

Stage I, immature: the gonad (belonging to young females that have not taken part in reproduction) consists of two thin and whitish parallel filaments. Oogonia have a characteristic large nucleolus and abundant cytoplasm (size range 10-28 $\mu \mathrm{m}$, mean \pm SD $15.3 \pm 10$ $\mu \mathrm{m}$ ), while primary oocytes (PO) have an abundant cytoplasm and several nucleoli (size range 17-83 $\mu \mathrm{m}$, mean \pm SD $44.9 \pm 20 \mu \mathrm{m}$ ) (Fig. 3a).

Stage II, developing: the ovary appears light orange in colour with eggs not visible to the naked eye. Primary oocytes and cortical alveoli oocytes (CAO) with very small lipid droplets (size range 61-142 $\mu \mathrm{m}$, mean \pm SD $85.4 \pm 27.4 \mu \mathrm{m})$ are present. The follicle layer is thick (Fig. 3b).

Stage III, maturing: orange gonads fill almost entire abdominal cavity; eggs are visible to the naked eye. The ovary tissue shows oocytes at different stages of vitellogenesis that are surrounded by an evident follicular layer. In early vitellogenic oocytes (EVO size range 124-288 $\mu \mathrm{m}$, mean \pm SD $226.1 \pm 45.5 \mu \mathrm{m}$ ) the yolk droplets are in the periphery of the cytoplasm; the nucleus is not round and a circular zone consisting of oil droplets of various size is localized around the nucleus. Late vitellogenic oocytes (LVO, size range 294-517 $\mu \mathrm{m}$, mean \pm SD $358.8 \pm 57.3 \mu \mathrm{m}$ ) show continuous yolk accumulation until it obscures the cortical alveoli with more and larger yolk droplets occupying the whole cytoplasm. Their nucleus shows rounded nucleoli (Fig. $3 c)$. The zona radiata of EVO and LVO is homogeneous and begins to regress in thickness.

Stage IV, mature: dark orange gonads that fill the entire abdominal cavity; individual orange eggs are distinguishable wrapped in a sturdy transparent tunica albuginea (Fig. 2d). A few primary oocytes and many mature eggs in advanced late vitellogenesis (ALVO) that reach maximum dimensions (size range 376-943 $\mu \mathrm{m}$, mean \pm SD $702.7 \pm 138.6 \mu \mathrm{m}$ ) are visible. Complete fusion of yolk droplets does not occur at ALVO stage (Fig. 3d). The zona radiata of ALVO is very thin (Fig. $3 e$ ). Sperm are deposited in the oviducts and ovarian lumen, where they may be stored for a long time, being nourished by cells of the luminal epithelium (Fig. 4).

Stage V, spent: the gonad appears flaccid and reddish. The tissue is collapsed (Fig. 3f) and characterized by oocytes in $\mathrm{PO}$ and in reabsorption.

In mature females, at least two populations of oocytes were recognized at any one time, as shown in Figure 5: a fairly synchronous population of ALVO and a more heterogeneous population of smaller oocytes.

In males, the macroscopic and microscopic stages of maturity were the following:

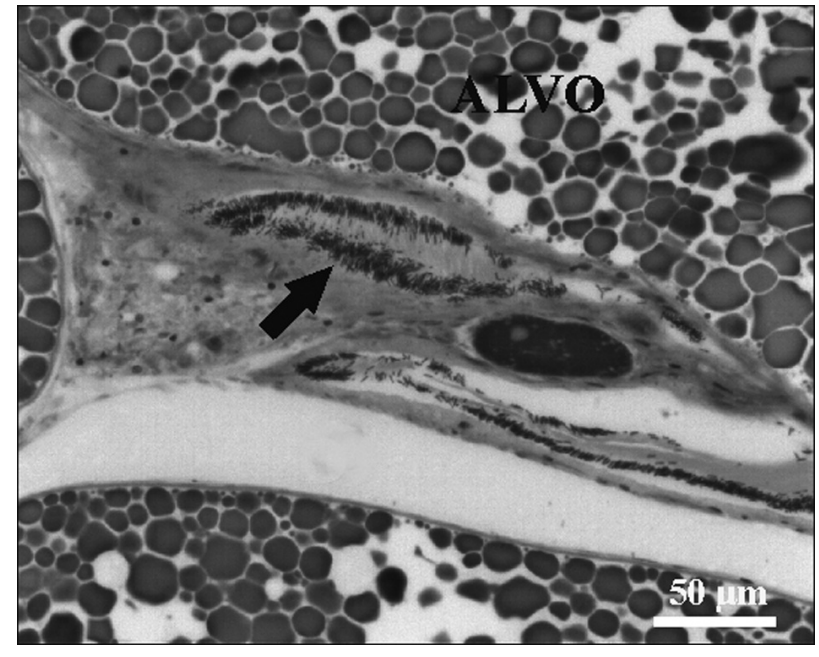

FIG. 4. - Section through mature ovary of Cataetyx alleni. Arrow indicates spermatozoa.

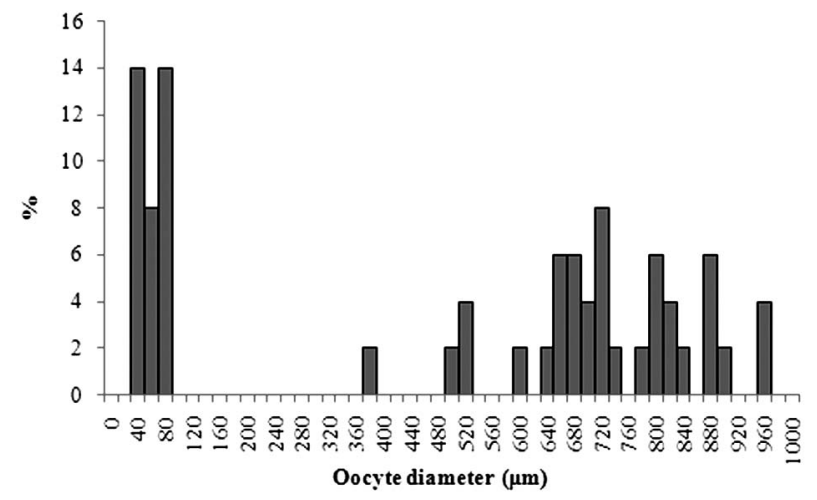

FIG. 5. - Size-frequency distribution of oocytes determined from histological sections for some mature ovaries of Cataetyx alleni.

Stage I, immature: small and translucent testes are made up of distinct lobes. Spermatogenesis has started, but testes lack a well-defined tubular system. Only spermatogonia (SPG) are present (Fig. 6a).

Stage II, developing: whitish testes. Spermatogenesis is generalized with all spermatogenic stages (Fig. 6b).

Stage III, maturing: white gonads fill almost the entire abdominal cavity. Spermatogenic cysts at all stages of development are present with spermatids (SPD) rodshaped and stringy (filiform) spermatozoa (SPZ) that can be observed in all tubules (Fig. 6c).

Stage IV, mature: white gonads fill the entire abdominal cavity (Fig. 2b). Spermatogenic activity is intense. Greatly enlarged tubules are fully filled with spermatozoa (SPZ). Sometimes nests of spermatogonia on the walls of the tubules and spermatids are present (Fig. 6d).

Stage V, spent: testes are flaccid and short. Collapsed tubules are again full of spermatozoa. The spermatogenic activity is very limited, with residual sperm (Fig. 6e).

In immature females the SL was 64 to $68 \mathrm{~mm}$, while in immature males it was 43 to $67 \mathrm{~mm}$. The smallest 

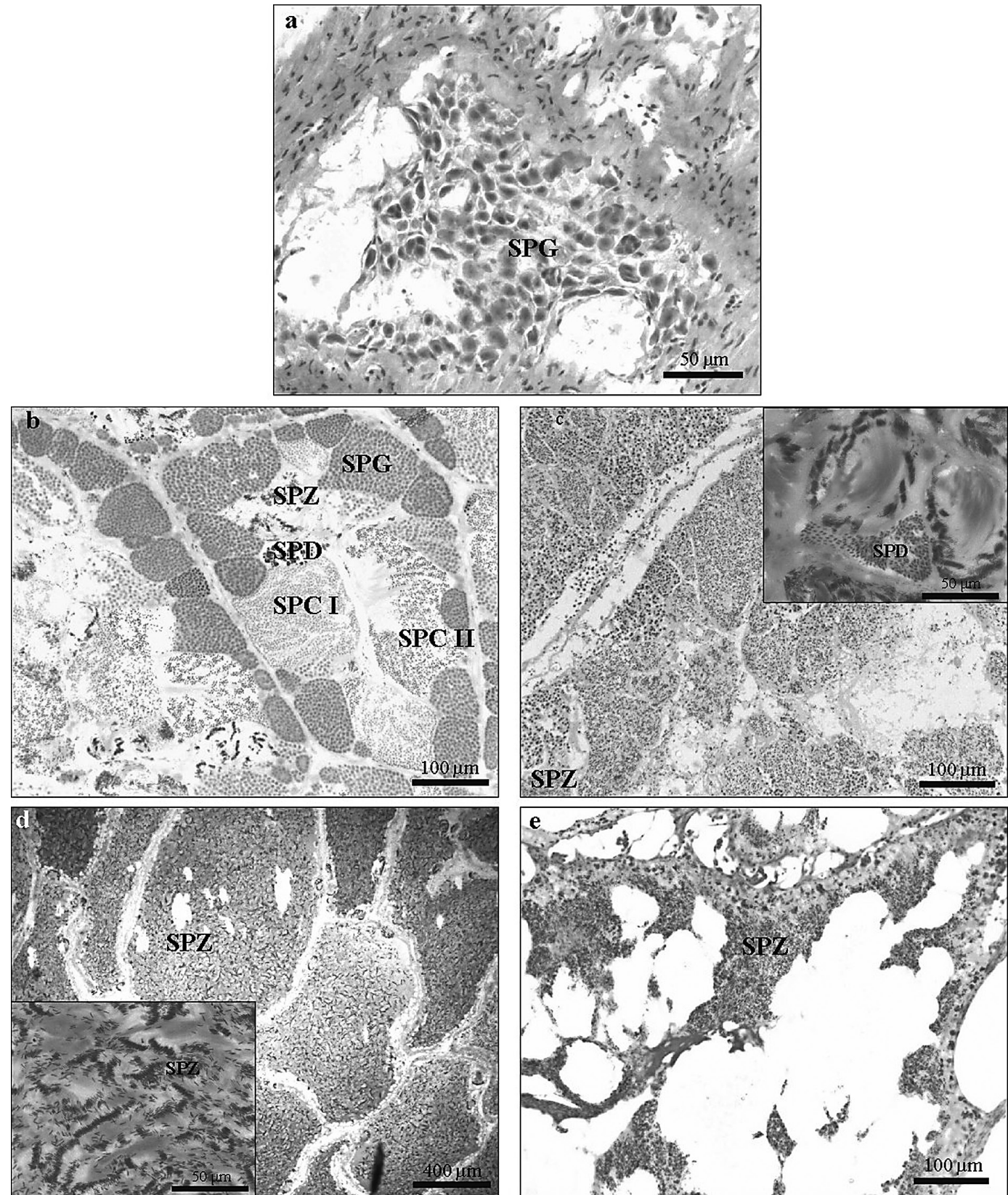

FIG. 6. - Transverse sections of Cataetyx alleni males illustrating spermatogenesis. (a) Immature stage (I) containing: SPG, spermatogonia. (b) Developing stage (II), in which an intense spermatogenic activity is observed; SPG, spermatogonia and SP I and II, primary and secondary spermatocytes; SPD, spermatids; and SPZ, spermatozoa. (c) Maturing stage (III). (d) Mature stage (IV) with tubules filled with spermatozoa. (e) Post-spawning stage (V), with spermatogenic activity limited.

TABLE 2. - Number of females (F) and males (M) of Cataetyx alleni at immature (I), developing (II), maturing (III), mature (IV) and spent (V) stages for each sampled month. (+) indicates fertilized females.

\begin{tabular}{|c|c|c|c|c|c|c|c|c|}
\hline & January & March & May & June & July & August & September & November \\
\hline F stage I & & 2 & 2 & & & & & \\
\hline F stage II & & & & & 1 & & & \\
\hline F stage III & & & 1 & 1 & 1 & & & 1 \\
\hline F stage IV & $2(+)$ & & & 1 & & & 1 & $1(+)$ \\
\hline F stage V & & 2 & & & & 1 & & \\
\hline M stage I & 3 & & 1 & & & & & \\
\hline M stage II & & 1 & 2 & & 1 & & & \\
\hline M stage III & & & & & & 2 & 2 & \\
\hline M stage IV & & & & & & & & 4 \\
\hline M stage V & 1 & & & & & & & \\
\hline
\end{tabular}


mature female and male had an SL of 77 and $83 \mathrm{~mm}$, respectively, while the largest ones had an SL of 114 and $103 \mathrm{~mm}$, respectively.

The maturing female specimens were detected in May, June, July and November, while the mature ones were found in June, September, November and January, with fertilized individuals only in the last two months. The maturing males were found in August and September, and the mature ones in November. One spent specimen with testes again full of spermatozoa in January was observed. The mature and spent males were found in the same period as the fertilized females (Table 2).

\section{DISCUSSION}

In the present paper we have reported reproductive data of the bythitid Cataetyx alleni for the southeastern Sardinian Sea (central-western Mediterranean). As reported by Relini Orsi and Relini (1973) for the Gulf of Genoa (Ligurian Sea), this species may be considered a common component of the deep population of the southeastern Sardinia deep waters, though it is not dominant (Follesa et al., 2010).

Total size distribution appeared similar to that of the other Mediterranean data. Our observed ranges of standard length (43-116 mm) were in agreement with Ligurian (57-122 mm, Relini Orsi, 1974) and Balearic data (30-110 mm, Morales-Nin, 1990). However, in the Adriatic Sea larger individuals (90-120 mm TL) than those caught in our area were observed (Ungaro et al., 2001).

The smallest size of mature specimens caught in southeastern Sardinian deep-waters $(83$ and $77 \mathrm{~mm}$ SL for males and females, respectively) was different from that found by Relini Orsi (1974), who stated that males became mature at smaller sizes $(65-70 \mathrm{~mm} \mathrm{SL})$ and females at larger sizes (only one sampled mature female at $122 \mathrm{~mm} \mathrm{SL}$ ).

Until now, the viviparous nature of $C$. alleni had been supported only by the existence of a copulatory organ in males. In this paper, for the first time, the internal fertilization has been demonstrated by the finding of spermatozoa in the ovarian cavity. The spermatozoa, filiform in shape, were found free only in females containing mature eggs, whereas maturing individuals have never shown free spermatozoa in the ovary.

In general, brotulid species are known to possess storage chambers for spermatophores in which the sperm is preserved. Few viviparous brotulids of the genera Calamopteryx, Oligopus, Microbrotula and Brosmophysis possess permanent storage structures in the posterior portion of the testes. Nielsen et al. (1968) suggest that the development of these structures may be a device ensuring that the spermatozoa are kept alive in the female until the eggs mature. However, our studied species showed a testis type common to other teleosteans and did not have spermatophores or similar structures. This aspect, also found in other brotulids such as Calamopteryx goslinei (Nielsen et al., 1968), was confirmed by Relini Orsi (1974), who also observed free spermatozoa in the penis of $C$. alleni.

The histological study of oogenesis showed some cellular characteristics typical of viviparous fishes (e.g. Xiphophorus helleri, Azevedo, 1974), such as the decrease in thickness of the zona radiata from maturing oocytes to mature ones that seemed to make possible intraovarian nutrition of the embryo. Another observed modification, associated with viviparity in fishes (Takemura et al., 1987) was the scarcity and small size of cortical alveoli. The role of the cortical alveoli in the strengthening of the chorion immediately after the fertilization of the eggs is known (Selman and Wallace, 1989; West, 1990). All these modifications are considered adaptations to the viviparous condition (Wourms, 1976).

Histological examination demonstrated that ovaries of $C$. alleni showed a 'group-synchronous' pattern, i.e. a mature female could exhibit at least two contemporaneous yet distinct populations of oocytes: one at the mature stage and a more heterogeneous one consisting of small immature oocytes (Wallace and Selman, 1981). The tendency for many eggs to ripen almost simultaneously is also typical among the brotulid forms (the viviparous genera Oligopus and Dinematichthys and oviparous Dicrolene and Benthocometes) (Mead et al., 1964).

Despite the paucity of the samples, the occurrence of mature females in summer (June and September), autumn (November) and winter (January) could suggest a long reproductive period. This result further emphasized the data on the Ligurian Sea reported by Relini Orsi (1974), who observed a maturation of gametes during the summer (June). A prolonged spawning is probably related to seasonal variability in food supply (Coggan et al., 1998) and increases the chances of meeting a mate in low-density populations and the probability of survival of offspring. However, the occurrence of inseminated females only in November and January, in correspondence with the highest maturity of males, suggests a probable reproductive peak with copulation in autumn-winter.

In the evolution of viviparity, there has been a tendency away from a dependency of the embryo on its own yolk reserves (lecithotrophy) to a greater reliance on nutrients supplied by the mother (matrotrophy). The congener $C$. laticeps was clearly classed as an "obligate lecithotrophic livebearer". In lecithotrophy, a less evolved adaptation, little or no nutrient material crosses to the embryo from the maternal circulation and all, or nearly all, of the substrates for growth and metabolism are obtained from yolk reserves stored in the egg prior to fertilization (Grove and Wourms, 1991, 1994). As in oviparous fishes, in this condition yolk is the sole source of nourishment. In this study no embryos were observed in the histological section of the ovaries analysed. This lack of embryos does not allow us to conclusively establish the kind of dependency of embryos, but the deep-sea species $C$. alleni could probably also be classified as its congener. 


\section{ACKNOWLEDGEMENTS}

The authors wish to thank the Foundation "Banco di Sardegna", which co-financed the project.

\section{REFERENCES}

Azevedo, C. - 1974. Évolution des enveloppes ovocytaires, au cours de l'ovogenèse chez un Téléostéen vivipare, Xiphophoris helleri. J. Microsc., 21: 43-54.

Bañón, R. - 2001. New record of Cataetyx laticeps (Bythitidae) in northwestern Atlantic. Cybium, 25: 93-94.

Byrne, L.W. - 1906. A new species of Pteridium (Scopoli) from the north-east Atlantic. Ann. Mag. Nat. Hist., Ser., 7(18): 448-450.

Carrassón, M. and J.E. Cartes. - 2002. Trophic relationships in a Mediterranean deep-sea fish-community: partition of food resources, dietary overlap and connections within the benthic boundary layer. Mar. Ecol. Prog. Ser., 241: 41-55.

Carrassón, M. and J. Matallanas. - 1990. Preliminary data about the feeding habits of some deep-sea Mediterranean fishes. J. Fish. Biol., 36: 461-463.

Carrassón, M. and J. Matallanas. - 1994. Morphometric characteristic of the alimentary tract of deep-sea Mediterranean teleosts in relation to their feeding habits. J. Mar. Biol., 118: 319-322.

Carrassón, M. and J. Matallanas. - 2002. Feeding habits of Cataetyx alleni (Pisces: Bythitidae) in the deep western Mediterranean. Sci. Mar., 66 (4): 417-421.

Coggan, R.A., J.D.M. Gordon and N.R. Merrett. - 1998. Abundance, distribution, reproduction and diet of notacanthid fishes (Pisces: Notacanthiformes) from the north-east Atlantic. $J$. Fish. Biol., 52: 1038-1057.

Cohen, D.M. and J.G. Nielsen. - 1978. Guide to the identification of genera of the fish order Ophidiiformes with tentative classification for the order. NOAA Tech. Rep. NMFS Circ. 417: 1-72.

Follesa, M.C., A. Mulas, M. Murenu, A. Sabatini and A. Cau. 2005. Ampliamento delle conoscenze sulla fauna batiale dei Mari Sardi. Biol. Mar. Medit. 12: 517-521.

Follesa, M.C., C. Porcu, S. Cabiddu, A. Mulas, A.M. Deiana and A. Cau. - 2010. Deep-water fish assemblages in the centralwestern Mediterranean (south Sardinian deep-waters). J. Appl. Ichthyol. (in press).

Goodwin, N.B., N.K. Dulvy and J.D. Reynolds. - 2002. Life-history correlates of the evolution of live bearing in fishes. Phil. Trans. Roy. Soc. London B, 357: 259-267.

Grier, H.J. -1981. Cellular organization of the testis and spermatogenesis in fishes. Am. Zool., 21: 345-357.

Grove, B.D. and J.P. Wourms. - 1991. The follicular placenta of the viviparous fish, Heterandria formosa. I. Ultrastructure and development of the embryonic absorptive surface. J. Morph. 209: 265-284.

Grove, B.D., and J.P. Wourms. - 1994. Follicular placenta of the viviparous fish, Heterandria formosa: 2. ultrastructure and development of the follicular epithelium. J. Morph. 220: 167-184.

Holden, M.J. and D.F.S. Raitt. - 1975. Manual de ciencia pesquera. Parte 2. Métodos para investigar los recursos y su aplicación. FAO Doc. Téc. Pesca, 115: 1-211.

Leis, J.M. and D.S. Rennis. - 2000. Ophidiiformes: Bythitidae. In: Leis, J.M. and B.M. Carson-Ewart (eds.), The Larvae of IndoPacific Coastal Fishes, pp. 100-103. Leiden, Brill.

Matallanas, J. - 1983. Primera captura de Cataetyx alleni (Byrne,1906) (Pisces, Bythitidae) en el Mediterráneo español. Inv. Pesq., 47: 413-418.

Mead, G.W., E. Bertelsen and D.M. Cohen. - 1964. Reproduction among deep-sea fishes. Deep-Sea Res., 11: 569-596.

Merrett, N.R., J.D.M. Gordon, M. Stehmann and R.I. Haedrich. -
1991. Deep demersal fish assemblage structure in the Porcupine Seabight (Eastern North Atlantic): slope sampling by three different trawls compared. J. Mar. Biol. Ass. UK, 71: 329-358.

Morales-Nin, B. - 1990. A first attempt at determining growth patterns of some Mediterranean deep-sea fishes. Sci. Mar., 54(3): 241-248.

Morales-Nin, B. - 2001. Mediterranean deep-water fish age determination and age validation: the state of the art. Fish. Res., 51: 377-383.

Moranta, J., C. Stefanescu, E. Massutí, B. Morales-Nin and D. Lloris. - 1998. Fish community structure and depth related trends on the continental slope of the Balearic Islands (Algerian basin, western Mediterranean). Mar. Ecol. Prog. Ser., 171: 247-259.

Moranta, J., M. Palmer, E. Massutí, C. Stefanescu and B. MoralesNin. - 2004. Body fish size tendencies within and among species in the deep-sea of the western Mediterranean. Sci. Mar., 68(3): 141-152.

Nelson, J.S. - 2006. Fishes of the World, $4^{\text {th }}$ edn. NewYork: Wiley.

Nielsen, J.G. - 1986. Family Bythitidae. In: P.J.P. Whitehead, M.L. Bauchot, J.-C. Hureau, J. Nielsen and E. Tortonese (eds.), Fishes of the North-eastern Atlantic and the Mediterranean, pp. 1153-1157. UNESCO, Bungay.

Nielsen, J.G., A. Jespersen and O. Munk. - 1968. Spermatophores in Ophidioidea (Pisces, Percomorphi). Galathea Rep., 9: 239-254.

Relini Orsi, L. - 1971. Primo ritrovamento di un adulto di Oculospinus brevis Koefoed 1927 (Pisces, Brotulidae) in Mediterraneo. Ann. Mus. Civ. St. Nat. Genova, 78: 247-255.

Relini Orsi, L. - 1974. Note di anatomia e di biologia di Oculospinus brevis Koefoed 1927 (Osteichthyes Brotulidae). A contribution to the biology of Oculospinus brevis. Mem. Biol. Mar. Ocean., 4: 405-420.

Relini Orsi, L. and G. Relini. - 1973. Nuove segnalazioni di pesci nel Mar Ligure e composizione dell'ittiofauna (Osteitti) dei fondi strascicabili. Boll. Mus. Ist. Biol. Univ. Genova, 41: 51-62.

Relini, G., A. Peirano and L. Tunesi. - 1986. Osservazioni sulle comunità dei fondi strascicatoli del Mar Ligure Centro-Orientale. Boll. Mus. ht. Biol. Univ. Genova, 52(Suppl.1): 139-161.

Rohlf, F.J. - 2005. TpsDig, digitize landmarks and outlines, version 2.04. Department of Ecology and Evolution, State University of New York at Stony Brook.

Selman, K. and R.A. Wallace. - 1989. Cellular aspect of oocyte growth in teleosts. Zool. Sci., 6: 211-231.

Stefanescu, C., D. Lloris and J. Rucabado. - 1992. Deep-living demersal fishes in the Catalan Sea (western Mediterranean) below a depth of 1000 m. J. Nat. Hist., 26: 197-213.

Takemura, A., K. Takano and H. Takahashi. - 1987. Reproductive cycle of a viviparous fish, the white edged rockfish, Sebastes taczanowskii. Bull. Fac. Fish. Hokkaido Univ., 38: 111-125.

Ungaro, N., G. Marano and G. Rivas. - 2001. Notes on ichthyofauna of the deep basin of the Southern Adriatic Sea. Sarsia, 86: 153-156.

Wallace, R.A. and K. Selman. - 1981. Cellular and dynamic aspects of oocyte growth in Teleosts. Am. Zool., 21: 325-343.

West, G. - 1990. Methods of assessing ovarian development in fishes: a review. Aust. J. Mar. Freshwater Res., 41: 199-222.

Wourms, J.P. - 1976. Annual fish oogenesis. I. Differentiation of the mature oocytes and formation of the primary envelope. Dev. Biol., 50: 338-354.

Wourms, J.P. - 1991. Reproduction and development of Sebastes in the context of the evolution of piscine viviparity. Environ. Biol. Fish., 30: 111-126.

Wourms, J.P. and O. Bayne. - 1973. Development of the viviparous brotulid fish, Dinematichthys ilucoeteoides. Copeia, 1: 32-40.

Scient. ed.: J.B. Company.

Received April 19, 2010. Accepted November 11, 2010.

Published online March 14, 2011. 